\title{
DAMPAK KEBERADAAN SEKTOR PARIWISATA TERHADAP PENINGKATAN FAKTOR SOSIAL EKONOMI MASYARAKAT KAMPUNG TENUN SAMARINDA DI KOTA SAMARINDA KALIMANTAN TIMUR
}

\author{
I Wayan Sudarmayasa \\ Pariwisata Politeknik Negeri Samarinda KALTIM \\ Email: i_w_sudarmayasa@polnes.co.id \\ I Wayan Lanang Nala \\ Pariwisata Politeknik Negeri Samarinda KALTIM \\ Email: lanangnala@polnes.co.id
}

\begin{abstract}
The purpose of this study is to examine the contribution of the impact provided by the existence of tourist destinations on the social and economic influence of the local community's destination. This method uses qualitative descriptive method and purposive sampling method, focuses on the chairman of the business group. The results of this study indicate that there is a synergy between the existence of the tourism sector to improve the economy and social community in tourist destination areas.
\end{abstract}

Keywords: Tourism, Impact, economy, social, Destinations

\section{Pendahuluan}

Industri pariwisata Indonesia sekarang ini sudah semakin bertumbuh pesat, dilihat memiliki banyak potensi kekayaan alam dan kebudayaan melimpah yang sudah dikembangkan pemerintah untuk pembangunan di sektor pariwisata secara maksimal. Seperti menurut (Yoeti, 2008) mengungkapkan pemilihan sektor pariwisata sebagai salah satu alternatif kemiskinan cukup beralasan. Pariwisata bagaimanapun juga, memiliki andil dan memberikan kontribusi besar dalam 
meningkatkan kesejahteraan rakyat kecil di pedesaan, yang di mana kegiatan pariwisata dikembangkan di berbagai daerah.

Suatu destinasi atau Daerah destinasi sekarang ini bisa bisa mengatur akan daerahnya sendiri,mengelola daerahnya sendiri mulai dari penataan, pemeliharaan dan berdasarkan kearifan lokal sesuai bidangnya termasuk pariwisata. UU No.32 Tahun 2004 tentang otonomi daerah menyatakan bahwa daerah diberikan kebebasan dan kewenangan untuk menentukan arah pembangunan ekonominya masing-masing. Keberadaan Pariwisata diharapkan nantinya akan memberikan pengaruh ganda (Multiflier Effect) dalam perekonomian regional ( Adisasmita, 2005:2008) kepada semua komponen mulai dari pembuat kebijakan, pelaksana kegiatan sampai pemilik destinasi wisata. Namun yang terjadi adalah kadangkadang tidak semua komponen yang terlibat bisa menikmati "kue" dari keberadaan pariwisata itu baik secara perorangan, kelompok ataupun hal lain yang berhubungan dengan pengaruh keberadaan pariwisata itu sendiri.

Kota Samarinda adalah salah satu daerah yang ada di Kalimantan Timur yang juga mengembangkan kepariwisataan diberbagai bidang untuk mendongkrak pendapatan daerah baik itu potensi alam yang dimiliki seperti Potensi wisata Sungai dan hutan, potensi wisata religi seperti Masjid Islamic Centre, Pura Jagat Hita Karana, Budhis Centre, Kelenteng, Gereja Katedral, potensi wisata Kuliner seperti kampung Nasi Kuning, Kerajinan lokal daerah seperti kerajinan Sarung Tenun Samarinda dan Kerajinan Manik-manik,Potensi Budaya seperti budaya Dayak, serta berbagai macam dan bentuk wisata buatan, seperti kolam pemandian, waterboom park serta pusat perbelanjaan.

Sebagian besar pengunjung yang datang ke Samarinda pada umumnya banyak yang datang dari seputaran Kota Samarinda, seperti Kota Bontang, Kabupaten Kutai Timur, Kabuoaten Kutai Barat, Kabupaten Mahakam ulu serta kabupaten Kutai Kartanegara. Untuk mendukung dan membuat betah pengunjung di Samarinda, banyak sudah usaha maupun kegiatan yang dilakukan dilakukan oleh pemerintah Kota Samarinda untuk mengembangkan dan mempromosikan 284 JUMPA Volume 05, Nomor 02, Januari 2019 
pariwisata di Kota Samarinda antara lain dengan kegiatan festival Mahakam, membuat atraksi wisata sungai dan susur sungai, atraksi desa wisata Pampang ,dan atraksi kerajinan tenun Sarung Samarinda.

Pemakaian Sarung Tenun Samarinda sekarang sudah banyak dipakai oleh semua kalangan baik pemerintahan maupun swasta. Namun yang menjadi pertanyaan sekarang ini adalah penggunaan Sarung Tenun Samarinda tidak sepenuhnya menggunakan Kain sarung dari wilayah Kelurahan Tenun Dan pengerajin sarung itu sendiri. Di satu sisi memang keberadaan sarung samarinda berasal dari Kelurahan Tenun ini sehingga bisa membanggakan wilayah kampung tenun, tetapi dengan adanya produk sarung cetakan tentunya akan berpengaruh terhadap pendapatan masyarakat maupun peningkatan taraf hidup masyarakat pemilik Sarung Tenun Samarinda

Berdasarkan permasalahan diatas maka penulis melakukan penelitian dengan rumusan masalah " Bagaimana dampak keberadaan sektor pariwisata terhadap peningkatan faktor sosial ekonomi Masyarakat Kampung Tenun di Kota Samarinda Kalimantan Timur" di tengah persaingan global sekarang ini? Dengan penelitian ini penulis mengharapkan mengetahui bagaimana dampak sosial ekonomi masyarakat dengan keberadaan pariwisata di kampung mereka serta apakah dengan meningkatnya penggunaan sarung samarinda akan meningkatkan pula pendapatan mereka dari sisi ekonomi dan kehidupan sosial mereka?

\section{Landasan Teori dan Metode}

Teori yang dipakai dalam penelitian ini adalah teori Dampak Pengembangan Pariwisata, yang mana perkembangan pariwisata tentu saja akan memberikan dampak baik itu negatif maupun dampak positif bagi perkembangan itu sendiri. Menurut (Gayatri, Sosiologi Pariwisata , 2005) bahkan pariwisata dikatakan mempunyai energi dobrak yang luar biasa, yang mampu membuat masyarakat setempat mengalami metamorfosis dalam berbagai aspeknya. Dampak pariwisata 
merupakan wilayah kajian yang paling banyak mendapatkan perhatian dalam literatur, terutama dampak terhadap masyarakat lokal. Di sisi lain, dampak pariwisata terhadap wisatawan dan negara asal wisatawan belum banyak mendapatkan perhatian. Sedangkan yang kedua adalah teori dampak pariwisata terhadap kehidupan sosial budaya didokumentasikan dengan sangat baik oleh Smith (1977), yang pada intinya ingin menjawab tiga pertanyaan pokok, yaitu : (1) bagaimana karakteristik interaksi antara wisatawan dengan masyarakat lokal (hostguest); (2) bagaimana proses pariwisata dapat mengubah masyarakat dan budaya masyarakat tuan rumah, dan; (3) apakah perubahan tersebut menguntungkan atau merugikan bagi tuan rumah.

Metode yang dipakai dalam penelitian ini adalah metode pendekatan deskriptif kualitatif yang mengandung arti pemahaman akan fenomena sosial dan masalah manusia khususnya dampak akan keberadaan pariwisata .Metode pengambilan sample menggunakan teknik pengambilan sample Purposive Sampling, yaitu menemui pengerajin yang secara kebetulan berada di tempat atau lokasi di pusat kerajinan Sarung Tenun Samarinda. Sedangkan metode pengambilan data dilakukan dengan observasi,yaitu melihat secara langsung kelokasi penenunan Sarung Samarinda; wawancara dengan para pelaku pengrajin sarung Samarinda dan data kepustakaan yang berisi tentang data semua yang berhubungan dengan seluk beluk Sarung Samarinda itu sendiri, baik itu literatur, tulisan atapun website terpercaya. Lokasi dari penelitian ini adalah di Kelurahan Tenun Kecamatan Samarinda seberang atau ditempuh kurang lebih $8 \mathrm{~km}$ dari pusat Kota Samarinda, bisa dengan menggunakan fasilitas Jembatan Mahakam atau dengan menggunakan perahu sungai 


\section{Pembahasan}

\section{Keberadaan Wilayah Kampung Tenun}

Salah satu yang jadi program andalan wisata di Kota Samarinda saat ini adalah Kelurahan Kampung Tenun di wilayah Kecamatan Samarinda Seberang. Kampung Tenun berada kurang lebih berjarak 8 ( Delapan ) Km dari pusat kota Samarinda dengan melewati Jembatan ataupun Kapal Sungai. Daerah yang memiliki luas 9,66 km2 ini berpenduduk kurang lebih 8.711 (Delapan ribu tujuh ratus sebelas ) orang dari 13 ( Tiga belas) Rukun Tetangga. Banyak profesi di wilayah Kampung Tenun ini antara lain mulai dari pekerja swasta, Aparatur Sipil Negara, sampai anggota Dewan ada di daerah ini. Kelurahan yang tergolong baru berdasarkan hasil pemekaran ini berdasarkan Peraturan daerah Kota Samarinda Nomor 6 Tahun 2014 merupakan wilayah kelurahan dengan tipelogi Kerajinan dan Industri Kecil. Ada sebanyak 7 Kelompok industri di daerah ini dengan nama Kelompok Usaha Bersama (KUB). Dari masing-masing kelompok tersebut mereka masing-masing memiliki anggota antara 15-20 anggota. Dengan kondisi tersebutlah maka wilayah ini dijadikan sebagai pusat sentra kerajinan Tenun Sarung Samarinda.

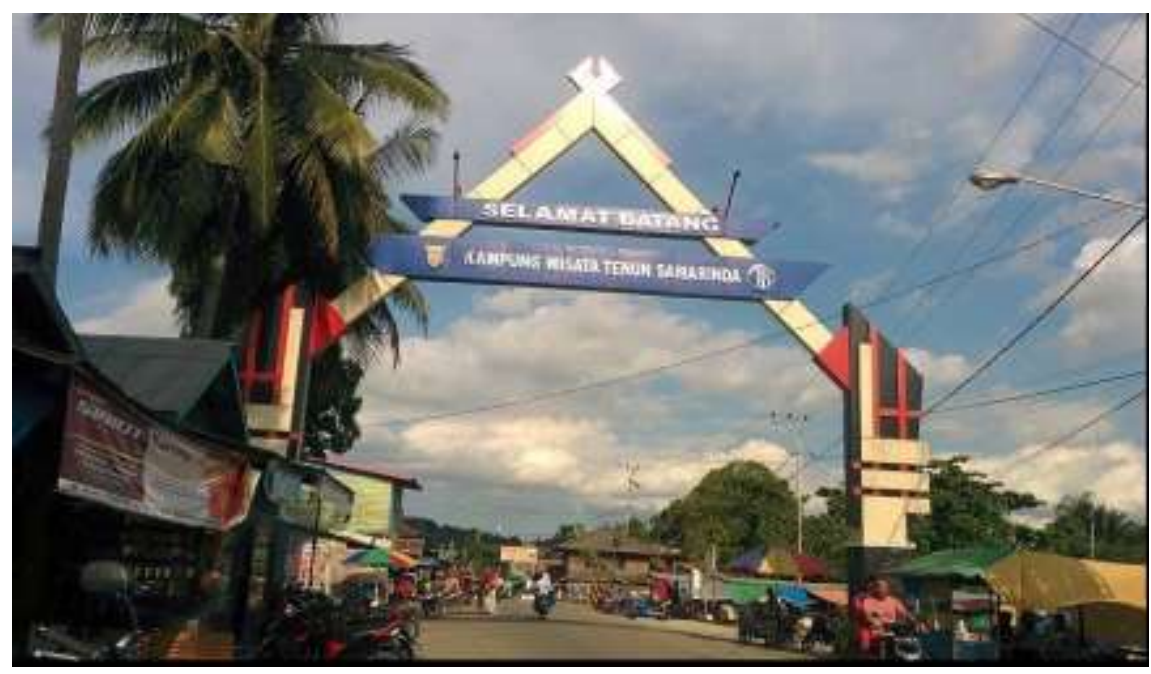

Gambar 1. Pintu Masuk Kampung Wisata Tenun Samarinda Sumber : Calmeyuri (2018) 
Faktor lain yang membuat berkembangnya Kelurahan Tenun ini adalah dengan kebijakan pemerintah Kota Samarinda yang menjadikan sebagai salah satu tujuan Daya Tarik Wisata di Kota Samarinda. Ada beberapa motif dari kerajinan Sarung Samarinda ini dibuat para pengerajin antara lain : motif cokkah manipih, rawa-rawa masak, ketan hitam, lebak suasa, belang hatta, mammaruwe, balok negara, krangsong, syejati, motif dayak tribal, motif soeharto, ayam palopo, motif catur, pucuk sobbi, hatta sikkola, balok kudara, bere-bere babaris, hatta kemmummu dan balok bontang. Mereka membuat sarung berbagai macam corak atau sesuai dengan pesanan pelanggan. Lebih membanggakan lagi adalah adanya dukungan pemerintah Kota Samarinda dengan digalakkannya pemakaian sarung tenun Samarinda di berbagai instansi pemerintahan, karyawan serta segenap komponen masyarakat Samarinda. Selain itu untuk mendongkrak penjualan didatangkan pula wisatawan ke wilayah ini baik wisatawan domestik maupun mancanegara.

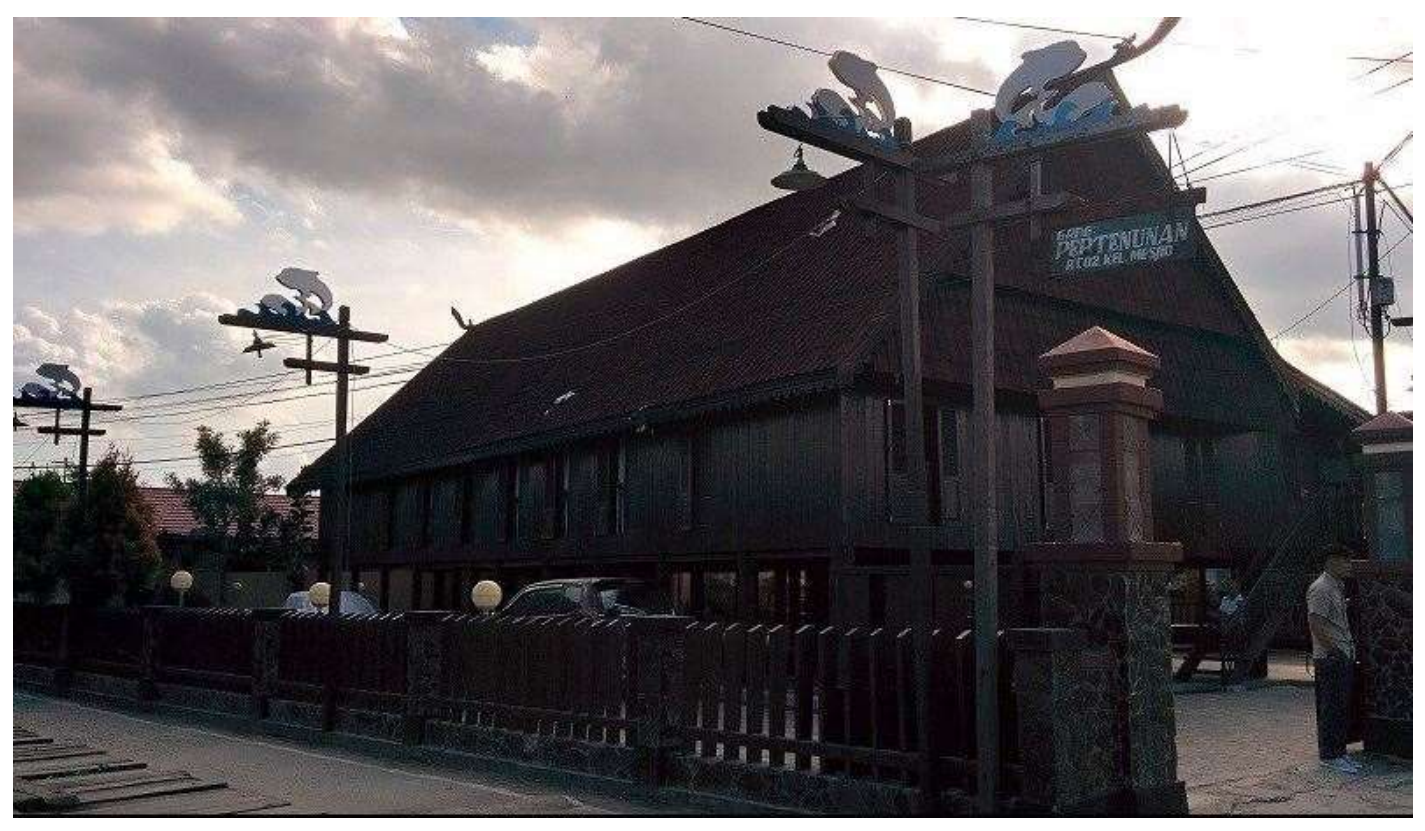

Gambar 2. Salah satu bangunan di Kampung Tenun Samarinda Sumber : Calmeyuri (2018) 
Dalam menjalankan Kerajinan Tenun Sarung Samarinda dan manik-manik, para kelompok mengajak para tetangga dan ibu-ibu disekitarnya. Selain itu, pemerintah juga mengajak para pelaku/pengrajin Sarung Tenun Samarinda melaksanakan pameran baik di dalam maupun luar negeri untuk lebih mengenalkan dan mempopulerkan Kerajinan Khas Sarung Tenun Samarinda di Indonesia dan mancanegara. Tujuan ini dilakukan agar kerajinan khas Sarung Samarinda ini bisa mengatasi pengangguran, mempertahankan tradisi kuno leluhur yang adiluhung, serta bisa mensejahkterakan masyarakat di sekitar wilayah Kampung Tenun. Hal ini senada dengan konsep Ismayanti dalam Rahman dan Tjoropandoyo, dimana pembangunan kepariwisataan salah satu tujuan pokoknya adalah; 1) Peningkatan pertumbuhan ekonomi,2) Menghapus kemiskinan, 3) Mengatasi pengangguran dan 4) Meningkatkan kesejahtraan masyarakat

\section{Dampak perekonomian masyarakat Kampung Tenun Samarinda}

Mata pencaharian kawasan kampung Tenun sejak dahulu, ( Masih dalah ruang lingkup kelurahan Mesjid) memiliki mata pencaharian yang berbeda-beda mulai dari Pelaut, Nelayan, Wirausaha sendiri hingga pegawai pemerintahan. Daerah yang didominasi pendatang dari sulawesi selatan ini berkembang sangat pesat seiring berkembangnya wilayah sampai ke daerah-daerah pinggiran. Apalagi sejak 2014, dengan keputusan pemerintah Kota Samarinda yang mana wilayah kampung Tenun dijadikan salah satu destinasi wisata kerajinan Sarung Tenun Samarinda. Kerajinan yang dahulunya hanya dijadikan sambilan di rumah, kini sudah menjadi kegiatan rutin yang menjadi penghasilan keluarga. Bukan hanya keterampilan membuat sarung Tenun Samarinda saja yang menjadi hasil dari kegiatan pengrajin disini, namun juga membuat manik-manik khas kalimantan Timur, khususnya suku Dayak. Rata -rata kegiatan menenun dan membuat manikmanik yang mereka lakukan bisa menghasilkan 1 ( satu) buah sarung sepanjang 4 meter dalam waktu kurang lebih 2 jam dam menghasilkan manik-manik 1-3 buah dengan jenis berbeda dalam tempo waktu 3 jam. Hasil ini bersifat fluktuatif 
dikarenakan warga yang bekerja di wilayah ini ada yang memang sudah mahir dan lama, ada juga para pengrajin yang baru memulai usaha kerajinan ini. Pengarajin Sarung Tenun Samarinda biasanya orang yang menetap di kampung Tenun dan meneruskan kepada generasi mereka secara turun temurun. Sedangkan untuk pembuat manik-manik ada yang memang menetap dan ada pula pendatang yang ikut belajar sebagai pengrajin untuk mengisi waktu luang mereka

\section{Perjalanan Usaha Pengerajin}

Dalam menjalankan usaha mereka, para pengerajin mendapatkan sumber modal dari berbagai macam sumber bentuknya. Sumber yang pertama yaitu sumber dari modal mereka sendiri, sehingga dalam proses pembuatannya para pengerajin menata sendiri dari nol dengan dukungan dana seadanya. Dengan modal sendiri ini masih banyak yang belum bisa dipenuhi oleh para pengerajin karena terbatasnya modal yang mereka miliki. Sumber Modal kedua yaitu modal dari fasilitas perbankan melalui Kredit Usaha Kecil Menengah yang memang diberikan keistimewaan oleh perbankan bagi usaha Kecil dan Menengah. Kendala yang dihadapi para pengerajin disini adalah masih banyak pengerajin yang takut akan tidak bisa mengembalikan pinjaman di bank, dikarenakan banyak para pengerajin yang belum memiliki tempat usaha/toko yang pasti, ini dikarenakan masih ada pengerajin yang berjualan dirumah, mengirim ketempat lain/kota lain maupun online. Sedangkan faktor yang ketiga dan sangat membantu adalah masih dibantunya para pengerajin oleh Dewan Kesenian dan Kerajinan Daerah Kota Samarinda dalam bentuk peralatan Tenun beserta kelengkapannya. Ini sangat membantu bagi mereka dalam menjalankan usaha menjadi lancar hingga keluar daerah.

\section{Dampak Pendapatan Pengerajin}

Dengan banyak sumber modal bagi pengerajin membuat pendapatan para pengerajin menjadi meningkat dari usaha pembuatan kerajinan sarung tenun dan manik-manik. Para pengerajin ( Pengerajin asli/pembuat sarung tenun asli dan 
bukan pengepul ) yang sekaligus membina para pengerajin rata-rata dalam sehari menghasilkan 1 ( satu ) buah sarung dan 5 buah manik-manik. Jika sarung Samarinda kelas 1 yang dihasilkan maka hanrganya sebesar Rp. 500.000,Rp.600.000,-, sedangkan yang kelas 2 berkisar antara Rp.300.000,- Rp.400.000,dalam tiap lembarnya, sedangkan dalam pembuatan manik-manik bisa menghasilkan Rp.5.000.,- Rp. 10.000,- per buahnya. Jika dirata-ratakan hasil pembuatan sarung dan kerajinan manik-manik dalam sebulan maka penghasilan kotor yang didapatkan pengerajin berkisar antara Rp. 10.000.000, - Rp.15.000.000,dalam sebulannya. Jika dipotong upah pekerja maka rata-rata pengerajin menghasilkan penghasilan Rp.5.000.000-Rp 10.000.000,- dalam sebulan. Penghasilan ini akan bersifat fluktuatif, jika kondisi lagi ramai dan merupakan hari besar seperti hari raya keagamaan, hari Besar Nasional, hari khusus bagi warga kota Samarinda, maka pendapatan akan meningkat pesat. Jika dahulu sebelum menjadi Daya tarik wisatawan, pendapatan biasa-biasa saja, namun sekarang ini sudah meningkat sangat signifikan dengan adanya pengembangan wilayah menjadi Daya tarik wisata Kampung Tenun.

Dalam pelaksanaan pendistribusian hasil kerajinannya para pengerajin melakukan pendistribusian hasil penjualannya dengan berbagai pola sesuai kemauan mereka.

a. Pengerajin menjual langsung sendiri hasil kerajinannya kepada konsumen, dimana proses ini dikarenakan sudah ada langganan, karena ada konsumen yang datang secara langsung ataupun melakukan pemesanan secara partai

b. Pengerajin menjual atau mengumpulkan hasil kerajinannya, yang kemudian dikumpulkan dalam kelompoknya untuk kemudian dijual oleh Kelompoknya yang biasa disebut Kelompok Usaha Bersa ( KUB ) yang masing-masing memiliki pimpinannya tersendiri, dan kemudian kelompoknya menjual dengan metode yang telah merka sepakati 
c. Pengerajin ada yang menjual dengan sistem Online, dimana para pengerajin di zaman modern ini sudah banyak yang melek teknologi sehingga mereka melakukan penjualan online dengan metode merka sendiri

d. Pengerajin juga menjual hasil kerajinan mereka dengan cara menitipkan di tempat atau toko lain untuk menjual hasil kerajinan mereka. Bukan hanya di seputaran Kota Samarinda para pengerajin menitipkan, namun mereka menitipkan hingga keluar kota seperti di Balikpapan.

Dengan metode para pengerajin seperti diatas, peningkatan khususnya perekonomian keluarga mereka mengalami peningkatan yang sangat menjanjikan di dalam usaha mereka dalam menekuni kerajinan Sarung Tenun Samarinda maupun kerajinan manik-manik.

\section{Dampak Sosial Masyarakat}

Secara kehidupan sosial masyarakat Kampung Tenun khususnya pengerajin sarung tenun samarinda, banyak yang mengalami perubahan baik itu perkembangan secara ekonomis, kebudayaan maupun psikologis.Dari segi perekonomian masyarakat pengerajin Sarung Tenun Samarinda sudah mengalami peningkatan perekonomian keluarga mereka semenjak dijadikannya wilayah mereka menjadi Daya Tarik Wisata oleh pemerintah daerah setempat. Tidak ada lagi kesenjangan perekonomian/kecemburuan sosial yang sangat signifikan diantara para pengerajin. Mereka hidup dalam suasana kebersamaan, membuat kerajinannya sendiri-sendiri dengan berbagai pola yang menurut kesepakatan para pengerajin. Sedangkan secara sosial kebudayaan tidak ada permasalahan yang sangat berarti di Kampung Tenun ini, dikarenakan rata -rata para penduduk berasal dari satu daerah yang sama dengan latar belakang budaya, adat, bahkan agama yang hampir sama, sehingga kehidupan masyarakat berjalan tentram. Begitu juga para pengerajin, dengan latar belakang keterampilan yang sama sebagai pengerajin sarung, maka tidak terlalu signifikan perbedaan yang terjadi di wilayah Kampung Tenun ini. 
1. Kendala dan Tantangan

Seiring dengan berkembangnya tantangan zaman, tentunya ada beberapa kendala yang dihadapi para pengerajin dalam menjalankan usahanya, selain faktor internal, juga faktor eksternal; antara lain :

- Keterbatasan akan bahan baku yang makin lama makin mahal dan berpotensi juga kemungkinan bahan akan habis dimasa mendatang, baik itu bahan baku benang, pewarna, maupun bahan lain yang diperlukan dalam menunjang usaha kerajinan ini

- Permasalahan regenerasi pengerajin sarung Samarinda sekarang ini sudah banyak yang mengalami penyusutan. Walaupun masih ada generasi penerus yang mewarisi keterampilan ini, namun itu masih sangat minim dan bahkan ada yang keturunan penenun tidak regenerasi sama sekali

- Persaingan antar para pengerajin yang suatu saat akan memungkinkan persaingan yang mengarah ke arah negatif karena persaingan usaha, harga, dan kebutuhan yang semakin meningkat

- Makin banyaknya sekarang ini muncul sarung Samarinda Cetakan ( Bukan Tenunan) yang membuat tantangan semakin keras. Di satu sisi sarung hasil tenunan yang harga nya ratusan ribu, sarung hasil cetakan dengan motif sama bisa mencapai harga yang hanya puluhan ribu saja. Ini menjadi tantangan yang di masa depan akan bisa mendesak hasil kerajinan tenun murni di masa depan

\section{Simpulan dan Saran}

Kerajinan Sarung Tenun Samarinda Di Kampung Tenun yang menjadi salah satu Daya Tarik Wisata di Kota Samarinda ini, secara langsung maupun tidak langsung sudah mengubah kehidupan masyarakat pemilik destinasi kearah yang lebih baik. Dari kehidupan perekonimian, dampak yang dirasakan para pengerajin Sarung Tenun di Wilayah Kampung Tenun sangat berdapak signifikan semenjak 
dijadikannya wilayah mereka menjadi destinasi dan daya tarik wisata, yang bukan hanya wisatawan domestik,namun juga wisatawan mancanegara. Hal ini sudah dibuktikan dengan semakin banyaknya keluarga para pengerajin yang menempuh pendidikan tinggi dan memiliki kehidupan yang layak. Dari dampak sosial, masyarakat mengalami perkembangan secara perekonomian, yang mana masyarakat mendukung akan keberadaan daya tarik wisata serta masih terjaganya pola kehidupan kebudayaan dan adat -istiadat daerah setempat apalagi didukung oleh kebijakan pemerintah Kota Samarinda sebagai daya tarik wisata kampung Tenun.

\section{Daftar Pustaka}

Abdillah, A.B.Y. Hamid, D. Topowijono, Dampak pengembangan Pariwisata terhadap kehidupan Masyarakat Lokal di Kawasan Wisata( Studi pada Masyarakat Sekitar wisata Wendit, Kabupaten Malang) Jurnal Administrasi Bisnis ( JAB) Vol.30 No 1 Januari 2016

Kisbiyanto, A. 2013, Dampak sosial ekonomi keberadaan pasar modern pada pasar tradisional ( Studi kasus Pasar Kota Boyolali);Skripsi;Yogyakarta: Universitas Negeri Yogyakarta

Dritasto,A. Anggraini, A.A. Analisis Dampak Ekonomi wisata Bahari terhadap pendapatan Masyarakat di Pulau Tidung, Reka Loka;Jurnal online Institut Teknologi Nasional nomor x, Vol xx Januari 2013

Hermawan, H., Dampak pengembangan desa wisata Nglanggeran terhadap ekonomi masyarakat lokal, ejournal.bsi.id/ejurnal/indexphp/jp, Pariwisata, Vol III No 2 September 2016

Koentjaraninggrat,1993.Metode-metode Penelitian Masyarakat, Jakarta.PT. Gramedia Pustaka Utama

Moleong, L., 2007, Metodelogi Penelitian Kualitatif, Bandung;PT Remaja Rosdakarya Offset

Nurwati, N. 2008. Pengaruh kondisi sosial dan ekonomi keluarga terhadap motivasi pekerja anak dalam membantu keluarga di kabupaten cirebon, Jawa Barat;Jurnal kependudukan Padjadjaran, vol 10,no 2,2008 ; 112-121 
Ekasaridan, P. Dharmawan, A.H. 2012. Dampak sosial ekonomi masuknya pengaruh internet dalam kehidupan remaja di pedesaan; Jurnal Sosiologi Pedesaan volume 6 nomor 1 2012; 57-71

Utari, S.T,. 2017. Dampak perkembangan Pariwisata terhadap kehidupam masyarakat pesisir Kelapa Lima Kupang,:Jurnal Master Pariwisata, Vol 4 nomor 1 2017:91-105

Sugiyono,2008, Metode penelitian Kuantitatif,Kualitatif dan R\&D, Bandung Alfabeta Undang-Undang No.10 tahun 2009 tentang Kepariwisataan

Undang-undang No.32 tahun 2004 Tentang Otonomi Daerah

https://kel-tenun.samarindakota.go.id/data jumlah penduduk /2018https://samarindakota.bps.go.id/kecamatan samarinda seberang dalam angka 2018

\section{Profil Penulis}

I Wayan Sudarmayasa, Salah satu staff Pengajar Jurusan Pariwisata di Politeknik Negeri Samarinda Kalimantan Timur. Alumnus Diploma IV Pariwisata Universitas Udayana 2002 dan Alumnus S2 Magister Pariwisata Universitas Udayana 2012.

I Wayan Lanang Nala, Staff Pengajar Jurusan Pariwisata di Politeknik Negeri Samarinda Kalimantan Timur, Alumnus Diploma IV Pariwisata Udayana 2001 dan Alumnus S2 Double Degree Indonesia Prancis (DDIP) Magister Pariwisata Universitas Udayana 2013, saat ini menjabat sebagai Ketua Jurusan Pariwisata Politeknik Negeri Samarinda Periode 2016- 2020. 